\title{
Dimenhydrinate and metoclopramide alone or in combination for prophylaxis of PONV
}

\author{
L.H.J. Eberhart MD, \\ W. Seeling MD, \\ B. Ulrich MD, \\ A.M. Morin MD, \\ M. Georgieff MD
}

Purpose: Dimenhydrinate and metoclopramide are inexpensive antiemetic drugs. Metoclopramide, especially, has been studied extensively in the past, but there are no studies on the combination of both drugs for prevention of postoperative nausea and vomiting (PONV).

Methods: One hundred and sixty male inpatients undergoing endonasal surgery were randomized to receive one of four antiemetic regimens in a double-blind manner: placebo, $1 \mathrm{mg} \cdot \mathrm{kg}^{-1}$ dimenhydrinate, $0.3 \mathrm{mg} \cdot \mathrm{kg}^{-1}$ metoclopramide, or the combination of both drugs was administered after induction of anesthesia. Patients received a second dose of these drugs six hours after the first administration to mitigate their short half-life. Standardized general anesthesia included benzodiazepine premedication, propofol, desflurane in $\mathrm{N}_{2} \mathrm{O} / \mathrm{O}_{2}$ vecuronium, and a continuous infusion of remifentanil. Postoperative analgesia and antiemetic rescue medication were standardized. Episodes of vomiting, retching, nausea, and the need for additional antiemetics were recorded for $24 \mathrm{hr}$. The incidences of PONV were analyzed with Fisher's Exact test and the severity of PONV (rated by a standardized scoring algorithm) with the Jonckheere-Terpestra-test.

Results: The incidence of patients free from PONV was $62.5 \%$ in the placebo-group and increased to $72.5 \%$ in the metoclopramide-group $(P=0.54), 75.0 \%$ in the dimenhydrinate-group $(P=0.34)$, and $85.0 \%$ in the combination- group $(P=0.025)$. In the latter group, the severity of PONV was reduced compared with placebo treatment ( $P=0.017$; Jonckheere-Terpestra-test).

Conclusion: Dimenhydrinate and metoclopramide were ineffective in reducing the incidence and the severity of PONV. Their combination reduced the incidence of PONV compared with placebo.

Objectif : Le dimenhydrinate et le métoclopramide sont des antiémétiques pas chers. Beaucoup d'études ont déjà été faites, avec le métoclopramide surtout, mais aucune avec la combinaison des deux comme moyen de prévention des nausées et des vomissements postopératoires (NVPO).

Méthode : Cent soixante patients masculins qui devaient subir une intervention endonasale ont consenti à participer à une étude prospective, randomisée et en double aveugle, et à recevoir un des quatre traitements antiémétiques suivants : un placebo; I mg.kg- I de dimenhydrinate; $0,3 \mathrm{mg} \cdot \mathrm{kg}$ - I de métoclopramide ou une combinaison des deux médicaments après l'induction de l'anesthésie. Ceux qui ont reçu du dimenhydrinate ou les deux médicaments ont eu une seconde dose de dimenhydrinate six heures après la première étant donné la courte demi-vie de ce médicament. L'anesthésie générale standardisée comprenait une prémédication de benzodiazépine, du propofol, du desflurane dans un mélange de $\mathrm{N}_{2} \mathrm{O} / \mathrm{O}_{2}$, du vécuronium et une perfusion continue de rémifentanil. L'analgésie postopératoire et les antiémétiques de rattrapage ont été standardisés. Les nausées, les vomissements, les efforts pour vomir et les demandes d'antiémétiques additionnels ont été enregistrés pendant $24 \mathrm{~h}$. Les incidences de NVPO ont été analysées selon le test Exact de Fisher et la sévérité des NVPO (estimée avec un algorithme de cotation standardisé), avec le test de Jonckheere-Terpestra.

Résultats : L'absence de NVPO a été de 62,5\% dans le groupe placebo et a augmenté à 72,5\% parmi les patients qui ont reçu du métoclopramide $(P=0,54)$; à $75,0 \%$ chez ceux qui ont reçu du dimenhydrinate $(P=$ $0,34)$ et à $85,0 \%$ chez ceux qui ont reçu les deux médicaments $(P=0,025)$. La sévérité des NVPO a été réduite chez les patients recevant la combinaison de médicaments, comparés à ceux qui ont reçu le placebo $(P=0,0$ I7; test de Jonckheere-Terpestra).

Conclusion : Le dimenhydrinate et le métoclopramide n'ont pas réduit l'incidence et la sévérité des NVPO. Leur combinaison, comparée au placebo, a diminué l'incidence de NVPO.

From the Department of Anaesthesiology, University of Ulm, Germany, D-89070 Ulm, Germany.

Address correspondence to: Dr. Leopold Eberhart. Phone: ++49-731-502-7931; Fax: ++49-731-502-7917;

E- mail: leopold.eberhart@medizin.uni-ulm.de

Accepted for publication May 6, 2000.

CAN J ANESTH 2000/47:8/pp 780-785 
$\mathrm{D}$ IMENHYDRINATE, an antihistaminic, and metoclopramide, a dopamine antagonist, were introduced into clinical practice more than $30 \mathrm{yr}$ ago and are among the most frequently used antiemetic drugs. They are well tolerated and inexpensive with few side effects and are sold as over the counter drugs in many countries.

Both drugs are used routinely although data describing the efficacy of dimenhydrinate is virtually nonexistent for adults ${ }^{1,2}$ or inconsistent. ${ }^{3,4}$ However, when asked about useful combinations of different antiemetics, the combination of dimenhydrinate and metoclopramide was mentioned frequently by anesthesiologists participating in a German survey attributing personal concerns of PONV. ${ }^{5}$ However, this combination has only been proven for chemotherapy associated vomiting. ${ }^{6,7}$

Thus, the aim of this randomized, double blind, placebo-controlled trial was to evaluate the antiemetic efficacy of a metoclopramide-dimenhydrinate combination $v s$ both drugs alone.

\section{Methods}

The local ethics committee approved the study. Written and informed consent was obtained from the participating patients. A sample size estimate performed prospectively revealed that 38 patients in each group were necessary to detect an absolute reduction of $30 \%$ with a two-tailed test $(\alpha: 0.05 ; \beta: 0.2)$ when the incidence of PONV in the placebo-group is $40 \%$ (this incidence was assumed from previous studies). Thus, a total of 160 ASA 1-2 men undergoing endonasal surgery (e.g. septoplasty, rhinoplasty, and septorhinoplasty) were enrolled into the study. According to a computer generated randomization plan, they were chosen to receive one of four treatments in a double-blind manner. The following drugs were administered intravenously immediately after induction of anesthesia:

1. Placebo group: saline

2. Metoclopramide-group: $0.3 \mathrm{mg} \cdot \mathrm{kg}^{-1}$ metoclopramide

3. Dimenhydrinate-group: $1 \mathrm{mg} \cdot \mathrm{kg}^{-1}$ dimenhydrinate 4. Combination-group: $\quad 1 \mathrm{mg} \cdot \mathrm{kg}^{-1}$ dimenhydrinate $+0.3 \mathrm{mg} \cdot \mathrm{kg}^{-1}$ metoclopramide

Six hours after the first administration of the study medication, a second dose of the same drug was administered intravenously. Metoclopramide and dimenhydrinate can be diluted together in $100 \mathrm{ml}$ saline. This mixture is chemically and physically stable for at least 24 $\mathrm{hr}$ (results of a gas chromatographic analysis [unpublished observation]).
The day before surgery, patients were interviewed for risk factors that might contribute to PONV (e.g. previous PONV, susceptibility to motion sickness, smoking habits). Patients receiving antiemetics, or suffering from nausea or vomiting in the two weeks before surgery, or those with known allergy against any of the drugs used were excluded from the study.

All patients fasted starting at 10:00 p.m., the night before surgery and received premedication with oral dipotassium clorazepate in the evening and in the morning before surgery.

General anesthesia was standardized: after insertion of the $i v$ canula, a continuous infusion of remifentanil, 10-20 g. $\cdot \mathrm{kg}^{-1} \cdot \mathrm{hr}^{-1}$, was established. Propofol, 2 $\mathrm{mg} \cdot \mathrm{kg}^{-1}$, was used for induction of anesthesia. Tracheal intubation was facilitated with $0.1 \mathrm{mg} \cdot \mathrm{kg}^{-1}$ vecuronium. Anesthesia was maintained using desflurane in end-expiratory concentrations of $2-3 \%$. The lungs were ventilated with $\mathrm{N}_{2} \mathrm{O} / \mathrm{O}_{2}$ using a fresh gas flow of $11 . \mathrm{min}^{-1}$. Intraoperatively, remifentanil infusion was adjusted to keep mean arterial blood pressure within a range of $60-75 \mathrm{mmHg}$. Before surgery, local anesthesia with mepivacaine combined with adrenaline as a vasoconstrictor to minimize intraoperative bleeding was applied by the surgeon. Postoperatively the nasal passages were packed. No throat pack or gastric tube was used. Since no neuromuscular blocker was repeated intraoperatively, no reversal agents were used at the end of surgery.

Postoperative analgesia was achieved with $100 \mathrm{mg}$ diclofenac $p r$ or, when contraindicated, with $1 \mathrm{~g}$ metamizole $i v$. Additionally, $0.05-0.1 \mathrm{mg} \cdot \mathrm{kg}^{-1}$ piritramide $i v$ was given on demand.

In the recovery room, the patients were monitored for the occurrence of nausea and emetic episodes (retching or vomiting). The patients were visited on the ward $2,5,8$, and $24 \mathrm{hr}$ after surgery by two of the authors (LE \& BU). Both the patients and the nursing staff were asked whether an emetic episode had occurred. Patients rated nausea using a four-point scale (none-mild-moderate-severe).

Droperidol, 0.5-1 mg, was administered when the patient suffered moderate or severe nausea or had two or more emetic episodes within two hours. This was followed by $12.5 \mathrm{mg}$ dolasetron when droperidol was ineffective.

\section{Statistical analysis}

The main outcome variable of this study was the number of men free from nausea and vomiting (= "no PONV"). This was defined as absence of any emetic episode and no nausea throughout the postoperative observation period. Significance was calculated with 
the ${ }^{2}$-test with the Fisher-Yates' correction. Fisher's Exact test was used for post- hoc analysis.

According to Korttila, ${ }^{8}$ an additional analysis of the severity of PONV was performed. For this purpose, the severity of PONV during the $24 \mathrm{hr}$ observation interval was categorized into four degrees using the following standardized scoring algorithm that has been used in similar trials: ${ }^{2}$

"no PONV": Absence of any emetic episode and nausea (as defined above).

"mild PONV": 1) the patient had only mild nausea. 2) one emetic episode or short lasting nausea of any severity $(<10 \mathrm{~min})$ occurred, but was triggered by an exogenous stimulus, e.g. drinking, eating, or postoperative movement. After this event, nausea was diminished and the patient felt well again throughout the entire observation period. No antiemetic drug was necessary.

"moderate PONV": 1) the patient had 1-2 emetic episodes or moderate or severe nausea without exogenous stimulus. 2) the patient required antiemetic therapy once.

"severe PONV": The patient had more than two emetic episodes or was nauseated more than twice (moderate or severe). The administration of at least one antiemetic was necessary.

The results of this categorization (a $4 \times 4$ contingency table, see Table III) were analyzed using the procedure described by Jonckheere. 9 This test is very similar to the non-parametric Kruskal-Wallis-test but is optimized to detect trends within the data with ordered categories. The asymptotic version of the test was calculated by a recursive procedure performed with the StatXact statistical package (CYTEL Software Corporation, Cambridge, MA 02139, USA). All other analyses were performed with StatView 4.5 (Abacus Concepts, Inc. Berkeley, CA 94704, USA). For all tests, a level of $\alpha=$ 0.05 was considered statistically significant.

Results

The biometric data (Table I) and anesthetic and surgical parameters (Table II) showed no difference among the groups. There were also no differences among the groups concerning risk factors for PONV.

The incidence of patients without PONV was not changed from $62.5 \%$ in the placebo-group to $72.5 \%$ in the metoclopramide-group $(P=0.54), 75.0 \%$ in the dimenhydrinate-group $(P=0.34)$. In the combination-group more patients $(85.0 \%)$ stayed completely free form PONV $(P=0.025$; placebo vs. combination). The severity of PONV was only reduced in the latter group (Table III). This could be proven by calculating the table of ordered severity of PONV using the procedure of Jonckheere. ${ }^{9}$ The $P$-value for the two-tailed asymptotic test was $P=0.017$ for placebogroup $v$ s the combination-group. The reduction of the severity of PONV induced by metoclopramide or dimenhydrinate alone was not statistically significant (metoclopramide $v$ s placebo: $P=0.27$; dimenhydrinate vs placebo: $P=0.12$ ).

The incidences of side effects were the same in all four groups. Dry mouth (placebo: $\mathrm{n}=8$; metoclopramide: $\mathrm{n}=7$; dimenhydrinate $\mathrm{n}=10$; combination: $\mathrm{n}=9$ ) and headache (placebo: $\mathrm{n}=5$; metoclopramide: $\mathrm{n}=3$; dimenhydrinate $\mathrm{n}=5$; combination: $\mathrm{n}=5$ ) were most frequent. No other relevant side effects were observed.

\section{Discussion}

There are only a few recent studies with dimenhydrinate or other antihistaminics. Two trials using dimenhydrinate to prevent PONV in children after strabismus surgery ${ }^{3}$ and adenotonsillectomy ${ }^{4}$ showed conflicting results regarding its effectiveness. In female in-patients PONV was reduced by repeated doses of dimenhydrinate. However, postoperative nausea and vomiting could not be prevented completely in a high number of patients. ${ }^{2}$

Many studies have been performed using metoclopramide as an antiemetic. Rowbotham ${ }^{10}$ reviewed several of these and concluded that there is a trend towards increased effectiveness when higher doses of the drug are used (e.g. $20 \mathrm{mg}$ instead of $10 \mathrm{mg}$ ). However, metoclopramide showed less effectiveness than droperidol and $5-\mathrm{HT}_{3}-$ receptor antagonists. ${ }^{11-13}$ In several other studies, metoclopramide was found to be ineffective in preventing PONV. ${ }^{4}$ This was attributed to the short duration of effect of the drug. ${ }^{10,14}$ Thus, we decided to give a second dose of both drugs six hours after the first administration since the plasma half life of both drugs, metoclopramide and dimenhydrinate, is similar (about 4-6 $\mathrm{hr}^{15,16}$ ).

However, when analyzing our data retrospectively, we found that patients in the placebo group very rarely developed PONV eight or more hours postoperatively. Thus, it can be speculated whether the second administration of the antiemetic was necessary. Instead of repeating the drugs it would have been more appropriate and less complicated to administer the drugs at the end of surgery than during induction of anesthesia.

Since there were no exclusion criteria with regard to the patients' proneness to develop PONV, the likelihood to suffer from PONV without antiemetic prophylaxis was calculated using a risk score for prediction of PONV. ${ }^{17}$ Applying a logistic regression analysis to 
TABLE I Patient related data (biometric data, risk factors for developing PONV). Data is reported as absolute and relative frequency and mean with standard deviation where appropriate.

\begin{tabular}{|c|c|c|c|c|c|}
\hline & & $\begin{array}{l}\text { placebo } \\
(n=40)\end{array}$ & $\begin{array}{l}\text { metoclopramide } \\
(n=40)\end{array}$ & $\begin{array}{l}\text { dimenhydrinate } \\
(n=40)\end{array}$ & $\begin{array}{l}\text { metoclopramide } \\
+ \text { dimenhydrinate } \\
(n=40)\end{array}$ \\
\hline Age & {$[\mathrm{yr}]$} & $38 \pm 12$ & $36 \pm 14$ & $37 \pm 17$ & $39 \pm 13$ \\
\hline Weight & {$[\mathrm{kg}]$} & $79 \pm 10$ & $77 \pm 11$ & $78 \pm 12$ & $79 \pm 11$ \\
\hline Height & {$[\mathrm{cm}]$} & $176 \pm 9$ & $177 \pm 8$ & $178 \pm 7$ & $176 \pm 7$ \\
\hline Body mass index & {$\left[\mathrm{kg} \cdot \mathrm{m}^{-2}\right]$} & $25.2 \pm 4.0$ & $24.6 \pm 2.7$ & $25.0 \pm 3.1$ & $25.5 \pm 3.6$ \\
\hline ASA-group I & {$[\mathrm{n}(\%)]$} & $25(62.5)$ & $24(60.0)$ & $22(55.0)$ & $24(60.0)$ \\
\hline ASA-group II & {$[\mathrm{n}(\%)]$} & $15(37.5)$ & $16(40.0)$ & $18(45.0)$ & $16(40.0)$ \\
\hline previous PONV & {$[\mathrm{n}(\%)]$} & $10(25.0)$ & $8(20.0)$ & $6(15.0)$ & $8(20.0)$ \\
\hline no previous surgery & {$[\mathrm{n}(\%)]$} & $6(15.0)$ & $9(22.5)$ & $10(25.0)$ & $9(22.5)$ \\
\hline no previous PONV & {$[\mathrm{n}(\%)]$} & $24(60.0)$ & $23(57.5)$ & $24(60.0)$ & $23(57.5)$ \\
\hline motion sickness & {$[\mathrm{n}(\%)]$} & $8(20.0)$ & $7(17.5)$ & $8(20.0)$ & $11(27.5)$ \\
\hline non-smoker & {$[\mathrm{n}(\%)]$} & $22(55.0)$ & $20(50.0)$ & $22(55.0)$ & $24(60.0)$ \\
\hline risk score for PONV & {$[\%]$} & $28.1 \pm 1$ & $30.4 \pm 15.6$ & $26.5 \pm 13.3$ & $29.9 \pm 16.2$ \\
\hline
\end{tabular}

TABLE II Surgical and anaesthesiological data reported as absolute and relative frequency and mean and standard deviation where appropriate. ${ }^{*}$ Desflurane: the median endexpiratory concentration is shown.

\begin{tabular}{|c|c|c|c|c|c|}
\hline & & $\begin{array}{l}\text { placebo } \\
(n=40)\end{array}$ & $\begin{array}{l}\text { metoclopramide } \\
(n=40)\end{array}$ & $\begin{array}{l}\text { dimenhydrinate } \\
(n=40)\end{array}$ & $\begin{array}{l}\text { metoclopramide } \\
+ \text { dimenhydrinate } \\
(n=40)\end{array}$ \\
\hline time of anesthesia & {$[\mathrm{min}]$} & $140 \pm 48$ & $140 \pm 52$ & $140 \pm 70$ & $130 \pm 46$ \\
\hline time of surgery & {$[\mathrm{min}]$} & $115 \pm 42$ & $115 \pm 46$ & $110 \pm 69$ & $95 \pm 42$ \\
\hline propofol & {$[\mathrm{mg}]$} & $170 \pm 32$ & $170 \pm 49$ & $180 \pm 47$ & $170 \pm 46$ \\
\hline remifentanil & {$\left[\mathrm{g} \cdot \mathrm{kg}^{-1} \cdot \mathrm{hr}^{-1}\right]$} & $11.8 \pm 5.2$ & $10.2 \pm 4.2$ & $10.7 \pm 4.9$ & $10.5 \pm 3.3$ \\
\hline vecuronium & {$[\mathrm{mg}]$} & $8 \pm 2$ & $8 \pm 2$ & $7 \pm 2$ & $7 \pm 2$ \\
\hline desflurane* & [Vol.\%] & $2.5 \pm 0.8$ & $2.8 \pm 0.5$ & $2.7 \pm 0.5$ & $2.7 \pm 0.6$ \\
\hline \multicolumn{6}{|l|}{ postoperative analgesia: } \\
\hline opioids & {$[\mathrm{n}=/ \%]$} & $15(37.5)$ & $15(37.5)$ & $14(40.0)$ & $20(50.0)$ \\
\hline non-steroidal drugs & {$[\mathrm{n}=/ \%]$} & $35(87.5)$ & $32(80.0)$ & $36(90.0)$ & $34(85.0)$ \\
\hline
\end{tabular}

TABLE III Incidence and severity of emetic episodes within the $24 \mathrm{hr}$ observation period. Data are presented as absolute and relative frequency. *difference between placebo and metoclopramide; †difference between placebo and dimenhydrinate; $\ddagger$ difference between placebo and combination.

\begin{tabular}{|c|c|c|c|c|c|c|}
\hline & & $\begin{array}{l}\text { placebo } \\
(n=40)\end{array}$ & $\begin{array}{l}\text { metoclopramide } \\
(n=40)\end{array}$ & $\begin{array}{l}\text { dimenhydrinate } \\
(n=40)\end{array}$ & $\begin{array}{l}\text { metoclopramide } \\
+ \text { dimenbydrinate } \\
(n=40)\end{array}$ & $P=$ \\
\hline patients with no PONV & {$[\mathrm{n}(\%)]$} & $25(67.5)$ & $29(27.5)$ & $30(75.0)$ & $34(85.0)$ & $0.54^{*}$ \\
\hline patients with PONV & {$[\mathrm{n}(\%)]$} & $15(37.5)$ & $11(72.5)$ & $10(25.0)$ & $6(15.0)$ & $\begin{array}{l}0.34 \dagger \\
0.025 \ddagger\end{array}$ \\
\hline \multicolumn{7}{|l|}{ severity of PONV } \\
\hline no PONV & {$[\mathrm{n}(\%)]$} & $25(64.5)$ & $29(72.5)$ & $30(75.0)$ & $34(85.0)$ & $0.27 *$ \\
\hline mild PONV & {$[\mathrm{n}(\%)]$} & $2(5.0)$ & $4(10.0)$ & $4(10.0)$ & $2(5.0)$ & $0.12 \dagger$ \\
\hline moderate PONV & {$[\mathrm{n}(\%)]$} & $5(12.5)$ & $2(5.0)$ & $4(10.0)$ & $2(5.0)$ & $0.017 \ddagger$ \\
\hline severe PONV & {$[\mathrm{n}(\%)]$} & $8(20.0)$ & $5(12.5)$ & $2(5.0)$ & $2(5.0)$ & \\
\hline patients with vomiting & {$[\mathrm{n}(\%)]$} & $7(17.5)$ & $5(12.5)$ & $4(10.0)$ & $2(5.0)$ & \\
\hline patients with nausea & {$[\mathrm{n}(\%)]$} & $15(37.5)$ & $11(72.5)$ & $8(20.0)$ & $6(15.0)$ & \\
\hline $\begin{array}{l}\text { patients with antiemetic } \\
\text { rescue medication }\end{array}$ & {$[\mathrm{n}(\%)]$} & $10(25.0)$ & $6(15.0)$ & $4(10.0)$ & $3(7.5)$ & \\
\hline
\end{tabular}


six main risk factors developed this score. In short these are gender, age, smoking habits, history of motion sickness and previous PONV, and duration of surgery. For each patient the individual risk for suffering from PONV was calculated. The results suggest that patients in all four groups had the same baseline risk (without antiemetic prophylaxis) of developing PONV (Table I). A homogenous group of male patients was studied to avoid interference with differences regarding the hormonal status and menstrual cycle in females.

Endonasal surgery is associated with a high incidence of PONV, which is reported between 34\% and 65\%.18,19 To improve the efficacy of antiemetic prophylaxis, a combination of antiemetic drugs has been suggested since there are at least four major receptor systems involved in the etiology of PONV. ${ }^{10}$ The combination of metoclopramide and dimenhydrinate is promising. On the one hand, anticholinergic action of the $\mathrm{H}_{1}$-antihistaminic dimenhydrinate can attenuate extrapyramidal side effects induced by antidopaminergic drugs. ${ }^{3,20}$ On the other hand, the prokinetic properties of metoclopramide can reduce gastroparesis that might be induced by anticholinergic effects of dimenhydrinate.

The incidence of PONV in male inpatients undergoing endonasal surgery under propofol-desfluraneremifentanil anesthesia receiving placebo treatment was about $38 \%$ in the present study. Among these, more than 50\% suffered from severe PONV (several emetic episodes and the need for antiemetic rescue medication). This incidence of PONV could be reduced to $27.5 \%$ and $25 \%$ with prophylactic administration of metoclopramide or dimenhydrinate, respectively. However, this reduction was not statistically significant. Only the combination of both antiemetics reduced the incidence and the severity of PONV to a clinically acceptable level (15\%).

\section{Conclusion}

There was a high incidence of postoperative nausea and vomiting in male patients after endonasal surgery. Neither metoclopramide or dimenhydrinate alone reduced the incidence of PONV. However, the combination of both drugs revealed a moderate additive effect: PONV was reduced from $37.5 \%$ in the placebogroup to $15.0 \%$. Thus, only the combination of metoclopramide and dimenhydrinate - not the single agents - can be recommended for male patients undergoing nasal surgery.

\section{References}

1 Stockall CA Postoperative nausea and vomiting - when will it stop? (Editorial) Can J Anaesth 1999; 46: 715-8.
2 Eberhart LHJ, Seeling W, Bopp TI, Morin AM, Georgieff $M$. Dimenhydrinate for prevention of post- operative nausea and vomiting in female in-patients. Eur J Anaesthesiol 1999; 16: 284-9.

3 Vener DF, Carr AS, Sikich N, Bissonnette B, Lerman J. Dimenhydrinate decreases vomiting after strabismus surgery in children. Anesth Analg 1996; 82: 728-31.

4 Hamid SK, Selby IR, Sikich N, Lerman J. Vomiting after adenotonsillectomy in children: a comparison of ondansetron, dimenhydrinate, and placebo. Anesth Analg 1998; 86: 496-500.

5 Eberbart LHJ, Morin AM, Felbinger TW, Falkner $\Upsilon$, Georgieff $M$, Seeling $W$. Results of a survey concerning postoperative nausea and vomiting. (German) AINS 1998; 33: 545-51.

6 Grunberg SM, Ehler E, McDermed JE, Akerley WL. Oral metoclopramide with or without diphenhydramine: potential for prevention of late nausea and vomiting induced by cisplatin. J Natl Cancer Inst 1988; 80: 864-8.

7 Chang T-C, Hsieh F, Lai C-H, et al. Comparison of the efficacy of tropisetron versus a metoclopramide cocktail based on the intensity of cisplatin-induced emesis. Cancer Chemother Pharmacol 1996; 37: 279-85.

8 Korttila $K$ The study of postoperative nausea and vomiting. Br J Anaesth 1992; 69(Suppll): 20-3.

9 Jonckbeere AR A distribution-free $k$-sample test against ordered alternatives. Biometrica 1954; 41: 133-45.

10 Rowbotham DJ. Current management of postoperative nausea and vomiting. Br J Anaesth 1992; 69(Suppll): 46-59.

11 Fujii Y, Saitoh $\Upsilon$, Tanaka H, Toyooka H. Prevention of PONV with granisetron, droperidol or metoclopramide in patients with postoperative emesis. Can J Anaesth 1998; 45: 153-6.

12 Fujii $\Upsilon$, Toyooka H, Tanaka H. Prevention of PONV with granisetron, droperidol and metoclopramide in female patients with history of motion sickness. Can J Anaesth 1997; 44: 820-4.

13 Naguib M, El Bakry AK, Khoshim MHB, et al. Prophylactic antiemetic therapy with ondansetron, tropisetron, granisetron and metoclopramide in patients undergoing laparoscopic cholecystectomy: a randomized, double-blind comparison with placebo. Can J Anaesth 1996; 43: 226-31.

14 Dundee JW, Clarke RSJ. The premedicant and antiemetic action of metoclopramide. Postgrad Med J 1973; 48(Suppl 4): 34-7.

15 Harrington RA, Hamilton CW, Brogden RN, Linkewich JA, Romankiewicz JA, Heel RC Metoclopramide. An updated review of its pharmacological properties and clinical use. Drugs 1983; 25: $451-94$. 
16 Blyden GT, Greenblatt DJ, Scavone JM, Shader RI.

Pharmacokinetics of diphenhydramine and a demethylated metabolite following intravenous and oral administration. J Clin Pharmacol 1986; 26: 529-33.

17 Apfel CC, Greim CA, Haubitz I, et al. A risk score to predict the probability of postoperative vomiting in adults. Acta Anaesthesiol Scand 1998; 42: 495-501.

18 Elhakim $M$. A comparison of intravenous ketoprofen with pethidine for postoperative pain relief following nasal surgery. Acta Anaesthesiol Scand 1991; 35: 279-82.

19 van den $\operatorname{Berg} A A$ The prophylactic antiemetic efficacy of prochlorperazine and ondansetron in nasal septal surgery: a randomized double-blind comparison. Anaesth Intensive Care 1996; 24: 538-45.

20 Schreibman DL. Treatment of a delayed reaction to droperidol with diphenhydramine (Letter). Anesth Analg 1990; 71: 105. 